Volume 3 Issue 2, September 2019: pp. 299-313. Copyright (c) 2019 HOLREV. Faculty of Law, Halu Oleo University, Kendari, Southeast Sulawesi, Indonesia. ISSN: 2548-1762 | e-ISSN: 2548-1754. Open Access at: http://ojs.uho.ac.id/index.php/holrev/

\title{
Implikasi Hukum Klausula Asuransi Jiwa dalam Perjanjian Kredit Perbankan
}

\author{
Legal Implications of Bank Credit Agreements that Contain Life Insurance \\ Clauses
}

\author{
Asri Sarif \\ Fakultas Hukum Universitas Halu Oleo \\ E-mail: asrisarif@uho.ac.id
}

\begin{abstract}
Every business always faces risks with detrimental impact, including the Bank's business in the field of credit. One of the ways taken by the Bank to eliminate or minimize the risk is to transfer the risk to insurance companies that are indeed permissible both in terms of business and juridical perspective. This paper aims to examine the legal implications of bank credit agreements that contain life insurance clauses, such as, among others, in the context of the parties' legal relations, legal implications caused by the existence of life insurance clauses in credit agreements, as well as legal protection aspects especially for debtor, using the method normative legal research. In the Bank Credit Agreement which includes the Life Insurance Clause, between the Debtor, the Bank, and the Insurance Company, there is no good legal relationship in order to guarantee the rights of each party, especially the debtor or the insured. The legal consequences are the increase in material/financial burden that must be borne by the debtor. Furthermore, this paper offers an idea of the form of legal protection for debtors as the weakest position in the relationship, so it could obtain assurance and legal protection.
\end{abstract}

Keyword: Legal Implications; Life Insurance Clause; Credit Agreement

Abstrak: Setiap usaha yang dijalankan selalu menghadapi risiko yang berdampak
merugikan termasuk juga usaha Bank di bidang pemberian kredit. Salah satu cara
yang ditempuh oleh Bank untuk menghilangkan atau meminimalisir risiko adalah
dengan mengalihkan risiko tersebut kepada perusahaan asuransi yang memang
dimungkinkan baik dari segi bisnis maupun dari segi yuridis. Tulisan ini ditujukan
untuk mengkaji implikasi hukum perjanjian kredit perbankan yang memuat
klausula asuransi jiwa, yakni antara lain dalam konteks hubungan hukum para
pihak, implikasi hukum yang ditimbulkan oleh adanya klausula asuransi jiwa dalam
perjanjian kredit, serta aspek perlindungan hukum khususnya terhadap debitur,
dengan menggunakan metode penelitian hukum normatif. Dalam Perjanjian Kredit
Bankyang memuat di dalamnya Klausula Asuransi Jiwa, antara Debitur, Bank, dan
Perusahaan Asuransi tidak terjalin hubungan hukum dengan baik dalam rangka 
menjamin hak-hak masing-masing pihak, khususnya debitur/tertanggung. Akibat hukum yang ditimbulkan adalah bertambahnya beban materiil/finansial yang harus ditanggung oleh debitur. Lebih lanjut tulisan ini menawarkan gagasan bentuk perlindungan hukum kepada debitur sebagai pihak yang kedudukannya paling lemah dalam hubungan tersebut, sehingga mampu mendapatkan jaminan kepastian dan perlindungan hukum.

Kata kunci: Implikasi Hukum; Klausula Asuransi Jiwa; Perjanjian Kredit

\section{PENDAHULUAN}

Lembaga perbankan mempunyai nilai strategis dalam kehidupan perekonomian suatu Negara, karena perannya sebagai perantara pihak-pihak yang mempunyai kelebihan dana (surplus of fund) dengan pihak-pihak yang kekurangan dan memerlukan dana (lack of fund). Perbankan bergerak dalam bidang perkreditan dan berbagai jasa lainnya. Bank melayani kebutuhan pembiayaan serta melancarkan mekanisme sistem pembayaran bagi semua sektor perekonomian. ${ }^{1}$

Bank sebagai lembaga intermediasi, memiliki fungsi sebagai perantara keuangan. Dalam peranannya, terdapat hubungan antara bank dengan nasabah didasarkan pada dua unsur yang saling terkait, yaitu hukum dan kepercayaan. Suatu bank hanya dapat melakukan kegiatan dan mengembangkan banknya, apabila masyarakat "percaya" untuk menempatkan uangnya dalam produk-produk perbankan yang ada pada bank tersebut. Berdasarkan kepercayaan masyarakat tersebut, bank dapat memobilisasi dana dari masyarakat untuk ditempatkan di banknya dan menyalurkan kembali dalam bentuk kredit serta memberikan jasa-jasa perbankan. ${ }^{2}$ Kredit dalam kegiatan perbankan merupakan kegiatan usaha yang paling utama, karena pendapatan terbesar dari usaha bank berasal dari pendapatan kegiatan usaha kredit yaitu berupa bunga dan provisi. ${ }^{3}$

Setiap kredit yang telah disetujui dan disepakati antara bank dan debitur wajib dituangkan dalam perjanjian kredit secara tertulis. Dalam praktik perbankan, bentuk dan format perjanjian kredit tidak mendapat pengaturan secara kongkret dalam UndangUndang Perbankan maupun peraturan-peraturan hukum lainnya yang terkait. Hal tersebut diserahkan sepenuhnya kepada bank yang bersangkutan. Namun demikian, ada hal-hal yang tetap harus dipedomani yaitu bahwa perjanjian tersebut rumusannya tidak

1 Muhamad Djumhana, Hukum Perbankan Di Indonesia, Bandung: Citra Aditya Bakti, 2000, hlm. ix.

2 Johanes Ibrahim, Mengupas Tuntas Kredit Komersial dan Konsumtif Dalam Perjanjian Kredit Bank (Perspektif Hukum dan Ekonomi), Bandung: Mandar Maju, 2004, hlm. 2-3.

3 Muhamad Djumhana, Op. cit., hlm. 365. 
boleh kabur atau tidak jelas, perjanjian tersebut sekurang-kurangnya harus memperhatikan keabsahan dan persyaratan secara hukum. ${ }^{4}$

Perjanjian kredit yang dibuat antara bank dengan nasabah debitur, dengan berlandaskan pada asas kebebasan berkontrak, dalam praktik perbankan di Indonesia, melahirkan format perjanjian standar atau perjanjian baku yang klausula-klausulanya telah ditentukan sebelumnya oleh bank. Nasabah calon debitur hanya diperhadapkan pada dua pilihan yaitu menerima atau menolak perjanjian itu (take it or leave it). Kondisi ini menciptakan posisi yang tidak berimbang antara bank dan debiturnya.

Seperti diketahui bahwa setiap usaha yang dijalankan selalu menghadapi risiko yang berdampak merugikan termasuk juga usaha bank di bidang pemberian kredit. Salah satu cara yang ditempuh oleh bank untuk menghilangkan atau meminimalisasi risiko tersebut adalah dengan mengalihkan risiko tersebut kepada perusahaan asuransi yang memang dimungkinkan baik dari segi yuridis maupun dari segi bisnis.

Terkait dengan perjanjian pemberian kredit dalam bisnis perbankan, perusahaan asuransi memberikan jaminan atas kelangsungan kehidupan bank dari risiko kerugian ekonomi, yakni risiko tidak dikembalikannya kredit yang telah dikucurkan kepada debiturnya. Implementasi hal tersebut oleh bank dalam memberikan fasilitas kredit kepada nasabah, menyertakan klausula asuransi dalam setiap perjanjian kredit yang dibuatnya. Hal ini bertujuan untuk melindungi bank dari risiko yang mungkin terjadi manakala debitur tidak dapat menunaikan kewajibannya melunasi kredit. Bentuk-bentuk asuransi yang ditawarkan terkait dalam pemberian kredit adalah asuransi barang jaminan kredit dan asuransi jiwa debitur.

Praktik Perjanjian kredit yang memuat klausula asuransi jiwa pada umumnya penutupan asuransi dilakukan dengan menempatkan Bank sebagai pihak yang menjadi penerima manfaat sedangkan Debitur sebagai Tertanggung yang tentu memikul kewajiban membayar premi. Premi yang dibayarkan oleh debitur jumlahnya tidak disebutkan secara jelas dalam klausula-klausula perjanjian kredit. Praktik yang demikian tidak menunjukkan adanya hubungan hukum antara debitur, bank, dan perusahaan asuransi yang jelas sehubungan dengan dimuatnya klausula asuransi jiwa dalam perjanjian kredit. Polis sebagai bukti otentik terjadinya hubungan hukum pertanggungan, di samping juga sebagai instrumen perlindungan hukum bagi tertanggung, tidak tertanggung dapatkan.

$4 \quad$ Ibid, hlm. 385. 
Pentingnya kejelasan hubungan hukum yang timbul antara para pihak, yakni Bank, Debitur dan Perusahaan Asuransi dalam perjanjian kredit yang mencantumkan klausula asuransi jiwa, adalah demi melindungi kepentingan hukum masing-masing pihak. Ketidakjelasan hubungan hukum di antara para pihak dapat berakibat sangat merugikan para pihak terutama bagi pihak yang keberadaannya dalam posisi yang lemah.

\section{METODE PENELITIAN}

Sebagai bahan analisis untuk mencapai suatu pembahasan yang sesuai dengan tujuan penulisan, maka dalam penelitian ini penulis menggunakan jenis penelitian hukum normatif (normative research), yaitu penelitian hukum yang meletakkan hukum sebagai sebuah bangunan sistem norma. Sistem norma yang dimaksud adalah mengenai asas-asas, norma atau kaidah dari peraturan perundang-undangan, putusan pengadilan, perjanjian serta doktrin (ajaran). ${ }^{5}$

Pengolahan data dan bahan-bahan hukum yang telah dikumpulkan, dilakukan dengan cara melakukan seleksi data berdasarkan kualitasnya, kemudian diklasifikasi menurut penggolongan bahan hukum dan disusun secara sistematis yang tentunya dilakukan secara logis untuk memudahkan analisis dan konstruksi penelitian dalam rangka mendapatkan gambaran yang jelas dan lengkap mengenai permasalahan yang dibahas.

\section{ANALISIS DAN PEMBAHASAN}

Implikasi Hukum dalam Konteks Hubungan Hukum antara Bank, Debitur dan Perusahaan Asuransi dalam Perjanjian Kredit yang Mencantumkan Klausula Asuransi Jiwa

Dalam dunia perbankan ada suatu prinsip yang selalu dipegang teguh yaitu kredit yang dikeluarkan harus dapat kembali sesuai dengan perjanjian. Mengingat karena dana tersebut adalah dana masyarakat penyimpan yang dipercayakan kepadanya. Oleh karena itu, bank harus dapat menghilangkan atau paling tidak mengurangi risiko yang mungkin timbul dalam setiap pemberian kredit. Salah satu langkah yang dilakukan adalah dengan penutupan asuransi kredit.

5 Mukti Fajar dan Yulianto Achmad, Dualisme Penelitian Hukum Normatif dan Empiris, Yogyakarta: Pustaka Pelajar, 2010, hlm. 33. 
Adanya ketentuan/klausula tentang asuransi jiwa dalam perjanjian kredit, menciptakan 3 (tiga) pihak yang memiliki hubungan hukum satu sama lain, baik secara langsung maupun tidak langsung, yaitu bank, debitur, dan perusahaan asuransi.

\section{Hubungan Hukum Bank dengan Debitur dalam Perjanjian Kredit yang Mencantumkan Klausula Asuransi Jiwa}

Hubungan hukum yang paling utama dan lazim antara bank dan nasabah adalah hubungan kontraktual. Hal ini berlaku hampir terhadap semua nasabah, baik nasabah debitur, nasabah deposan, ataupun nasabah nondebitur-nondeposan. Terhadap nasabah debitur, hubungan kontraktual tersebut berdasarkan suatu kontrak yang dibuat antara bank sebagai kreditur (pemberi dana) dan pihak debitur (peminjam dana). ${ }^{6}$

Dalam praktik perbankan modern, hubungan hukum dalam kredit tidak lagi semata-mata berbentuk hanya perjanjian pinjam-meminjam saja sebagaimana diatur dalam Pasal 1754-1769 KUHPerdata, melainkan adanya campuran dengan bentuk perjanjian yang lainnya seperti perjanjian pemberian kuasa dan perjanjian-perjanjian lainnya.

Terkait dengan penutupan asuransi, terlihat bahwa di samping nasabah memberikan kuasa kepada bank untuk memotong sejumlah dana untuk pembayaran premi asuransi, juga terdapat kuasa dari nasabah kepada bank untuk memotong dana klaim asuransi jiwa debitur guna pelunasan kewajiban nasabah kepada bank. Dengan perkataan lain bahwa bila dalam masa kredit, debitur meninggal dunia maka bank terlebih dahulu yang berkepentingan atas dana klaim yang didapatkan nasabah (tertanggung) untuk pelunasan kreditnya. Namun yang harus dipahami pula bahwa pemberian kuasa tersebut hanya terbatas pada pemotongan dana, bukan pemberian kuasa kepada bank untuk melakukan penutupan asuransi.

Melihat begitu luasnya kuasa yang diberikan kepada bank dengan sifatnya yang mutlak pula, akan berdampak besar bagi kepentingan debitur. Hal ini tentu berpotensi merugikan bagi debitur mengingat bank dapat bertindak sepihak berdasarkan cara-cara yang dikehendakinya.

6 Munir Fuady, Hukum Perbankan Modern (Buku Kesatu), Bandung: Citra Aditya Bakti, 2003, hlm. 100. 


\section{Hubungan Hukum Bank dengan Perusahaan Asuransi sebagai Implikasi adanya Klausula Asuransi Jiwa dalam Perjanjian Kredit}

Pentingnya kebutuhan akan minimalisasi risiko perkreditan mendorong bank untuk melakukan perjanjian kerja sama kemitraan dengan perusahaan asuransi untuk menutup jaminan-jaminan kredit maupun terhadap jiwa debiturnya dengan asuransi. Hal ini dilakukan oleh bank semata-mata dalam rangka perlindungan kepentingannya dari potensi kerugian. Pihak asuransi pun kemudian memanfaatkan peluang ini untuk mengembangkan pasarnya yang dikemas dengan model kerja sama saling menguntungkan dengan pihak bank. ${ }^{7}$

Mengenai kerja sama kemitraan antara perbankan dengan perusahaan asuransi dalam hal pemasaran produk asuransi melalui bisnis perbankan, Bank Indonesia telah mengeluarkan Surat Edaran Nomor No. 12/35/DPNP tertanggal 23 Desember 2010 tentang Penerapan Manajemen Risiko pada Bank yang Melakukan Aktivitas Kerjasama Pemasaran dengan Perusahaan Asuransi (Bancassurance). Surat Edaran diterbitkan dalam rangka mendukung perkembangan pasar keuangan, meningkatkan penerapan manajemen risiko oleh bank, serta melindungi kepentingan nasabah.

Terciptanya perjanjian kerja sama antara Bank dengan Asuransi melahirkan hak dan kewajiban bagi masing-masing pihak yang juga secara tidak langsung melahirkan keterikatan bagi tiap-tiap nasabah yang ingin mendapatkan fasilitas kredit dari bank untuk melakukan penutupan asuransi.

\section{Hubungan Debitur dengan Perusahaan Asuransi Terkait Adanya Klausula Wajib Asuransi Jiwa Dalam Perjanjian Kredit.}

Melihat penutupan asuransi jiwa debitur yang lahir dari perjanjian kredit Bank, secara yuridis debitur tidak mempunyai hubungan hukum secara langsung dengan perusahaan asuransi. Akan tetapi secara materiil, biaya premi yang dibayarkan kepada perusahaan asuransi adalah berasal dari debitur yang dipotong langsung oleh bank pada awal pencairan/realisasi kredit. Hal ini menunjukkan bahwa tertanggung dalam perjanjian asuransi tersebut adalah debitur. ${ }^{8}$

7 Baca lebih lanjut Surat Edaran Nomor No. 12/35/DPNP tanggal 23 Desember 2010 perihal Penerapan Manajemen Risiko pada Bank yang Melakukan Aktivitas Kerjasama Pemasaran dengan Perusahaan Asuransi (Bancassurance).

8 Bunyi Pasal 1 Ayat (3) Perjanjian Kerjasama BPD dengan Askrida yang menyebutkan bahwa “Tertanggung / peserta asuransi PA kreasi adalah debitur yang mendapatkan fasilitas kredit dari Bank 
Tertanggung dalam hal ini nasabah debitur tidak pernah mengadakan negosiasi penutupan asuransi, termasuk tidak ada kata sepakat di antara para pihak. Debitur sebagai tertanggung tidak diberikan kebebasan untuk memilih dan menentukan sendiri melakukan penutupan asuransi jiwa dengan perusahaan asuransi pilihannya. Penentuan perusahaan asuransi yang menutup asuransi jiwa debitur, sepenuhnya ditentukan oleh bank secara sepihak.

Ketentuan yang demikian berpeluang menimbulkan kerugian terhadap debitur, karena sebagai tertanggung yang juga membayar premi atas penutupan asuransi, debitur tidak memiliki kesempatan untuk menentukan sendiri isi perjanjian yang nantinya dimuat dalam polis asuransi. Debitur tidak mendapatkan kejelasan hukum tentang hak-hak yang seharusnya diperolehnya dari penutupan asuransi tersebut.

Menurut hemat penulis, penutupan asuransi jiwa di atas dilakukan dengan tidak menggunakan peluang yang diberikan oleh Pasal 1317 KUHPerdata yang menentukan bahwa dapat juga diadakan perjanjian untuk kepentingan orang ketiga, bila suatu perjanjian yang dibuat untuk diri sendiri, atau suatu pemberian kepada orang lain, mengandung syarat semacam itu. Siapa pun yang telah menentukan suatu syarat, tidak boleh menariknya kembali, jika pihak ketiga telah menyatakan akan mempergunakan syarat itu.

Praktik perbankan mengenalnya dengan istilah banker's clause yang dicantumkan dalam polis asuransi. ${ }^{9}$ Dengan metode penutupan asuransi demikian, debitur tetap menjadi tertanggung dan penanggungnya adalah perusahaan asuransi, sedangkan bank adalah sebagai pihak ketiga yang berkepentingan. Banker's clause dicantumkan berkenaan dengan penutupan asuransi terhadap jiwa debitur yang mendapatkan kredit dari bank yang namanya disebutkan dalam klausula tersebut. Adanya banker's clause mampu memberikan jalinan kepastian hubungan hukum kepada masing-masing pihak (Bank, Debitur dan Perusahaan Asuransi), mengingat pula bahwa banker's clause kekuatan hukumnya diakui oleh Pasal 1317 KUHPerdata.

Pembangunan Daerah Sulawesi Tenggara”. Telah dijelaskan sebelumnya bahwa Perjanjian Kerjasama tersebut berlaku bagi semua Kantor Cabang BPD Se-Sulawesi Tenggara, termasuk BPD Wakatobi.

9 Sutan Remy Sjahdeini, Kebebasan Berkontrak dan Perlindungan yang Seimbang Bagi Para Pihak Dalam Perjanjian Kredit Bank di Indonesia, Jakarta: Institut Bankir Indonesia, 1993, hlm. 287. 


\section{Implikasi Hukum Dicantumkannya Klausula Asuransi Jiwa dalam Perjanjian Kredit}

Perjanjian asuransi menciptakan tatanan hubungan hukum antara para pihak. Tatanan hukum ini melahirkan hak dan kewajiban. Menurut Sudikno Mertokusumo, tatanan yang diciptakan oleh hukum baru menjadi kenyataan apabila kepada subyek hukum diberi hak dan dibebani kewajiban. Setiap hubungan hukum yang diciptakan oleh hukum selalu mempunyai dua segi yang isinya di satu pihak "hak" sedang dipihak lain "kewajiban". Tidak ada hak tanpa kewajiban, sebaliknya tidak ada kewajiban tanpa hak. ${ }^{10}$ Begitu pula halnya yang terjadi dalam hubungan hukum asuransi, penanggung menerima pengalihan risiko dari tertanggung dan tertanggung membayar sejumlah premi sebagai imbalannya.

Penutupan asuransi yang lahir dari perjanjian kredit dinyatakan sebagai bentuk asuransi jiwa debitur. Artinya bahwa peristiwa yang dipertanggungkan adalah risiko meninggal dunia debitur. Dengan meninggalnya debitur selama jangka waktu kredit berlangsung, pelunasan kredit akan dibayarkan oleh perusahaan asuransi. Ketentuan pembayaran sejumlah uang sebagai akibat meninggalnya debitur hanya sebesar baki debet (sisa utang debitur) kepada bank ditambah bunga kredit 1 (satu) bulan. ${ }^{11}$

Lahirnya perjanjian asuransi jiwa debitur sebagai kewajiban yang ditentukan dalam perjanjian kredit membawa berbagai permasalahan yang menimbulkan akibat hukum yang berdampak merugikan bagi debitur. Masalah-masalah tersebut adalah sebagai berikut:

\section{Tertanggung dalam Perjanjian Asuransi Jiwa Debitur}

Keberadaan Klausula Asuransi Jiwa dalam Perjanjian Kredit melahirkan kewajiban bagi debitur untuk membayar sejumlah premi asuransi guna penutupan asuransi jiwa debitur. Pada kondisi demikian, sangat jelas bahwa Debitur juga berkedudukan sebagai Tertanggung. Namun demikian, debitur sebagai tertanggung tidak pernah melakukan penutupan asuransi dengan penanggung, begitu pula besaran premi yang harus dibayarkan timbul tidak berdasarkan kesepakatan antara debitur dengan penanggung/pihak asuransi, akan tetapi melalui kesepakatan antara Bank dengan pihak Asuransi. Perjanjian penutupan asuransi tidak mengindahkan kewajiban keterpenuhan syarat sahnya perjanjian sebagaimana dimaksud dalam Pasal 1320 KUHPerdata, juga

10 Sudikno Mertokusumo, Mengenal Hukum (Suatu Pengantar), Cetakan Keempat, Yogyakarta: Liberty, 2008, hlm. 41.

11 Ketentuan Pasal 6 Ayat (1) Perjanjian Kredit BPD Wakatobi Nomor: 227/KMG/135.006/4/12/Wci. Lebih lanjut dipertegas dalam Pasal 6 Ayat (2) Perjanjian Kerjasama BPD dan Askrida Nomor: 010/PKS/DIR/II/2012 tentang Program Asuransi PA Kreasi. 
termasuk syarat notifikasi yang secara khusus diatur dalam Pasal 251 KUHD. Realitas yang demikian jika dihubungkan dengan ketentuan Pasal 302, Pasal 303, dan Pasal 304 KUHD dapat disimpulkan bahwa bank adalah sebagai pihak yang berkepentingan, yang mengasuransikan jiwa debiturnya. Jadi yang dimaksud oleh ketentuan Pasal 304 sub 2 bahwa orang yang menjadi pihak lawan dari penanggung itu adalah tertanggung (verzekerde) yang sekaligus menjadi orang yang berkepentingan di dalam pertanggungan jiwa, itu adalah bank. Akan tetapi bilamana bank adalah tertanggung, seharusnya bank yang berkewajiban membayar premi kepada perusahaan asuransi, bukan debitur.

\section{Penentuan Jumlah Premi}

Premi adalah salah satu unsur yang paling penting dalam asuransi karena merupakan kewajiban utama yang wajib dipenuhi oleh tertanggung kepada penanggung. Dalam hubungan hukum asuransi, penanggung menerima pengalihan risiko dari tertanggung dan tertanggung membayar sejumlah premi sebagai imbalannya. Premi harus dibayar lebih dahulu oleh tertanggung, karena tertanggunglah pihak yang berkepentingan. ${ }^{12}$

Pada perjanjian kredit yang memuat klausula asuransi jiwa, pembayaran premi dilakukan sesaat setelah kredit terealisasi/dikucurkan. Bank langsung melakukan pemotongan sejumlah dana untuk pembayaran premi asuransi tersebut. Hal yang tidak lazim adalah, premi telah dilunasi oleh nasabah sesaat setelah kredit dikucurkan, namun pernyataan sepakat membuat perjanjian dengan pihak asuransi sebagai penanggung belum terjadi. Ketentuan ini menunjukkan bahwa setelah bank dan debitur sepakat melakukan perjanjian kredit, yang ditandai dengan ditandatanganinya akta perjanjian tersebut oleh kedua belah pihak, maka sejak saat itu pula pertanggungan jiwa debitur berjalan. Atau dengan kata lain, penanggung sejak saat itu telah menerima pengalihan risiko dari tertanggung.

Keabsahan perjanjian asuransi jiwa debitur menjadi hal yang dipertanyakan mengingat debitur yang diasuransikan jiwanya tidak pernah melakukan penutupan asuransi dengan pihak penanggung. Pembayaran premi hanya didasarkan karena ketentuan perjanjian kredit yang memuat klausula wajib asuransi, diikuti dengan pemberian kuasa oleh debitur kepada bank untuk melakukan pemotongan dana guna kepentingan pembayaran premi yang dikehendaki oleh bank. Keabsahan perjanjian

12 Abdulkadir Muhamad, Hukum Asuransi Indonesia, Cetakan Kelima, Bandung: Citra Aditya Bakti, 2011, hlm. 103. 
asuransi juga bergantung pada ketentuan Pasal 1320 KUHPerdata di samping juga harus memenuhi ketentuan atau syarat-syarat khusus yang ditentukan dalam KUHD.

\section{Polis Sebagai Akta Penutupan Asuransi}

Bilamana debitur adalah tertanggung dalam perjanjian penutupan asuransi, maka seharusnya debiturlah yang melakukan perjanjian penutupan asuransi dengan pihak penanggung. Debitur dengan asuransi yang menentukan syarat-syarat perjanjian dan disepakati bersama yang selanjutnya dimuat dalam polis. Polis harus diberikan kepada debitur, meskipun kemudian diserahkan kepada bank sebagai jaminan bagi bank untuk pelunasan kreditnya bilamana dikemudian hari selama masa kredit, debitur meninggal dunia. Bersamaan dengan polis tersebut, demi kepentingan bank dibuatlah klausula bank (banker's clause).

Polis juga mempunyai arti yang sangat penting bagi tertanggung, sebab polis itu merupakan bukti yang sempurna dan satu-satunya alat bukti tentang apa yang mereka (penanggung dan tertanggung) perjanjikan dalam perjanjian pertanggungan. Jadi bagi tertanggung, polis itu mempunyai nilai yang sangat menentukan bagi pembuktian haknya. Tanpa polis pembuktian akan menjadi sulit dan terbatas. ${ }^{13}$

\section{Jumlah Klaim}

Klaim merupakan konsekuensi dari suatu pertanggungan dimana pihak tertanggung yang mengalami suatu evenement mengajukan permohonan kepada penanggung agar kepadanya diberikan ganti rugi berupa uang atau pelayanan tertentu.

Pada praktik perjanjian kredit yang memuat klausula asuransi jiwa, pembayaran klaim dilakukan apabila dalam jangka waktu kredit berlangsung debitur/tertanggung meninggal dunia, maka perusahaan asuransi akan membayar klaim kepada bank guna pelunasan kredit tertanggung/debitur. Jumlah klaim yang dibayarkan hanya sebesar sisa kredit debitur kepada bank. Namun bilamana sampai jangka waktu kredit berakhir dan terhadap debitur tidak mengalami evenemen (meninggal dunia), debitur/tertanggung tidak akan mendapatkan pengembalian sejumlah uang layaknya perjanjian asuransi jiwa pada umumnya. Premi yang telah dibayarkan oleh debitur sepenuhnya menjadi keuntungan pihak penanggung. Hal demikian, karena penutupan asuransi jiwa debitur

13 Sri Redjeki Hartono, Hukum Asuransi dan Perusahaan Asuransi, Cetakan Kelima, Jakarta: Sinar Grafika, 2008, hlm. 124. 
tidak termasuk dalam jenis asuransi dwiguna yang mengandung aspek investasi, akan tetapi termasuk dalam jenis asuransi eka waktu (term oflife insurance), dimana bila sampai akhir jangka waktu asuransi tidak terjadi evenemen, maka tertanggung tidak akan mendapatkan pengembalian sejumlah uang dari penanggung.

Permasalahan dalam hal ini adalah penentuan jenis asuransi jiwa tersebut, tidak diketahui oleh debitur. Demi menghindari perselisihan dikemudian, seharusnya penentuan jenis asuransi jiwa yang mengover debitur tersebut dicantumkan dalam polis serta dijelaskan kepada tertanggung.

\section{Jangka Waktu Asuransi}

Jangka waktu asuransi jiwa dapat ditentukan untuk masa tertentu dan dapat pula ditentukan untuk selamanya tergantung kesepakatan penanggung dan tertanggung. Untuk jangka waktu perjanjian asuransi jiwa debitur, adalah disesuaikan dengan jangka waktu perjanjian kredit yang melahirkan penutupan asuransi tersebut.

Berakhirnya perjanjian kredit menunjukkan berakhirnya pula perjanjian asuransi. Jika sampai masa kredit berakhir (kredit telah terlunasi) tidak terjadi evenemen atas debitur, maka sejak itu pula perjanjian asuransi berakhir dan debitur tidak mendapatkan pengembalian sejumlah uang dari penanggung. Premi yang telah dibayarkan sepenuhnya menjadi keuntungan perusahaan asuransi.

\section{Perlindungan Hukum Terhadap Debitur dalam Perjanjian Kredit yang Mencantumkan Klausula Asuransi Jiwa}

Dalam masyarakat yang masih memiliki banyak keterbatasan dalam pemahaman atas hak dan kewajibannya, sifat perjanjian asuransi yang disiapkan sepihak (perjanjian standar) membuatnya rawan terhadap praktik bisnis dan isi perjanjian asli (polis) yang diterima oleh tertanggung yang tidak mendudukkan para pihak dalam keadaan yang seimbang, adalah tidak sesuai dengan pendekatan keadilan. Begitu juga halnya pembatasan hak tertanggung untuk terhadap pemilihan penanggung. ${ }^{14}$

Adanya klausula wajib asuransi jiwa terhadap debitur memiliki maksud dan tujuan untuk memberikan perlindungan kepada debitur, dimana apabila dalam masa kredit terhadapnya terjadi risiko meninggal dunia maka kreditnya akan terlunasi oleh sejumlah

\footnotetext{
14 A. Djunaedi Ganie, Hukum Asuransi Indonesia, Cetakan Kedua, Jakarta: Sinar Grafika, 2013, hlm. 72.
} 
uang yang diterimanya dari pihak asuransi. Disisi lain bagi kreditur, adanya klausula asuransi tersebut dapat menghindarkannya dari risiko kredit macet yang disebabkan oleh meninggalnya debitur. Sejauh itu terlihat bahwa adanya ketentuan tentang kewajiban asuransi jiwa bagi debitur menciptakan kondisi yang saling menguntungkan kepada masing-masing pihak.

Akan tetapi, dengan melihat penutupan asuransi jiwa debitur yang termasuk dalam jenis asuransi eka waktu yang tidak memberikan nilai investasi kepada debitur, seharusnya kewajiban pembayaran premi atas itu dibayarkan oleh bank dan bukan oleh debitur, karena penutupan asuransi tersebut lebih kepada kepentingan bank menghindari risiko terjadinya kredit macet akibat meninggalnya debitur.

Bilamana hingga masa akhir perjanjian tidak terjadi evenemen, premi yang telah dibayarkan oleh debitur hanya menciptakan keuntungan bagi bank (pendapatan dalam bentuk fee) dan bagi pihak perusahaan asuransi. Dalam kondisi ini nampaklah apa yang dimaksudkan oleh KUHPerdata bahwa Asuransi merupakan salah satu jenis perjanjian untung-untungan (Pasal 1774 KUHPerdata).

Walaupun perjanjian asuransi tidak termasuk perjanjian yang secara khusus diatur dalam KUHPerdata, akan tetapi lebih khusus diatur dalam KUHD, namun berdasarkan ketentuan Pasal 1 KUHD menentukan bahwa ketentuan umum perjanjian dalam KUHPerdata dapat berlaku pula bagi perjanjian asuransi. Oleh karena itu, ketentuanketentuan mengenai perjanjian dalam KUHPerdata tetap harus dipedomani dalam perjanjian asuransi demi kepentingan masing-masing pihak dalam perjanjian, khususnya tertanggung. Ketentuan-ketentuan yang utama adalah menyangkut syarat-syarat sahnya perjanjian serta asas-asas yang melandasi pelaksanaan perjanjian.

KUHD sebagai sumber pengaturan yang utama dari perjanjian asuransi, di dalamnya terdapat beberapa peraturan yang harus diperhatikan terkait hubungannya dengan perlindungan kepentingan tertanggung. Ketentuan yang paling mendasar untuk diperhatikan adalah menyangkut pembuktian terjadinya perjanjian asuransi, yang diatur dalam Pasal 255 sampai dengan Pasal 258 KUHD.

Di samping itu, bila ditinjau dari aspek UU Perlindungan Konsumen, tertanggung merupakan konsumen yang harus dilindungi secara hukum. Perlindungan terhadapnya merupakan suatu tuntutan yang tidak boleh diabaikan. Jaminan perlindungan hukum terhadap konsumen termasuk konsumen jasa perbankan dan perasuransian, dituangkan dalam ketentuan Pasal 4 UUPK yang memuat hak-hak bagi konsumen. Adanya ketentuan 
tersebut dapat menjadi instrumen hukum bagi setiap konsumen yang ingin memperjuangkan hak-haknya dalam setiap perjanjian yang berpotensi menimbulkan kerugian terhadapnya.

\section{KESIMPULAN}

Berdasarkan analisis dan pembahasan di atas, menunjukkan bahwa: pertama, hubungan hukum antara Debitur, Bank, dan Perusahaan Asuransi dalam perjanjian kredit yang mencantumkan klausula asuransi jiwa, tidak terjalin dengan baik dalam rangka menjamin hak-hak masing-masing pihak, khususnya debitur/tertanggung. Antara bank dengan debitur terjalin hubungan hukum hanya sebatas pada pemberian kuasa khusus mengenai pemotongan sejumlah dana milik debitur untuk kepentingan pembayaran premi asuransi. Kuasa tersebut tidak dapat dimaknai sebagai pelimpahan wewenang secara penuh dari debitur kepada bank untuk mewakilinya dalam segala hal yang berkaitan dengan penutupan asuransi jiwa debitur. Demikian halnya antara debitur dan perusahaan asuransi, tidak tercipta hubungan hukum secara langsung. Debitur/tertanggung tidak pernah melakukan penutupan asuransi jiwa dengan pihak asuransi. Tidak ada kata sepakat di antara para pihak. Debitur tidak diberikan kebebasan untuk memilih dan menentukan sendiri melakukan penutupan asuransi jiwa dengan perusahaan asuransi pilihannya. Penentuan perusahaan asuransi yang menutup asuransi jiwa debitur, sepenuhnya ditentukan oleh bank secara sepihak. Begitu pula halnya penutupan atas asuransi jiwa debitur tersebut dilakukan oleh bank dengan pihak asuransi.

Kedua, akibat hukum pencantuman klausula asuransi jiwa di satu sisi mewajibkan debitur untuk membayar sejumlah premi yang jumlahnya ditentukan berdasarkan kesepakatan bersama antara bank dan perusahaan asuransi yang dibayarkan lunas sesaat setelah permohonan kredit diterima dan direalisasi. Dilain sisi debitur hanya akan memperoleh haknya berupa pelunasan kreditnya kepada bank bilamana dalam masa kredit berjalan, terhadapnya mengalami risiko meninggal dunia.

Ketiga, Pencantuman klausula asuransi jiwa dalam perjanjian kredit bank, belum sepenuhnya atau masih kurang memberikan perlindungan hukum kepada debitur/tertanggung untuk mendapatkan pemenuhan hak-haknya. Adanya kewajiban penutupan asuransi terhadap jiwa debitur tidak serta merta memberikan perlindungan hukum kepada debitur/tertanggung. Perlindungan hukum yang dijamin khususnya bagi tertanggung yang diatur dalam peraturan perundang-undangan, yakni KUHPerdata, 
KUHD, serta Undang-Undang Perlindungan Konsumen belum sepenuhnya debitur/tertanggung dapatkan dalam perjanjian Asuransi Jiwa Debitur.

\section{Daftar Pustaka}

\section{Buku}

Djumhana, Muhamad, Hukum Perbankan Di Indonesia, Bandung: Citra Aditya Bakti, 2000. Fajar, Mukti dan Yulianto Achmad, Dualisme Penelitian Hukum Normatif dan Empiris, Yogyakarta: Pustaka Pelajar, 2010.

Fuady, Munir, Hukum Perbankan Modern (Buku Kesatu), Bandung: Citra Aditya Bakti, 2003. Ganie, A. Djunaedi, Hukum Asuransi Indonesia, Cetakan Kedua, Jakarta: Sinar Grafika, 2013. Hartono, Sri Redjeki, Hukum Asuransi dan Perusahaan Asuransi, Cetakan Kelima, Jakarta: Sinar Grafika, 2008.

Ibrahim, Johanes, Mengupas Tuntas Kredit Komersial dan Konsumtif Dalam Perjanjian Kredit Bank (Perspektif Hukum dan Ekonomi), Bandung: Mandar Maju, 2004.

Mertokusumo, Sudikno, Mengenal Hukum (Suatu Pengantar), Cetakan Keempat, Yogyakarta: Liberty, 2008.

Muhamad, Abdulkadir, Hukum Asuransi Indonesia, Cetakan Kelima, Bandung: Citra Aditya Bakti, 2011.

Sjahdeini, Sutan Remy, Kebebasan Berkontrak dan Perlindungan yang Seimbang Bagi Para Pihak Dalam Perjanjian Kredit Bank di Indonesia, Jakarta: Institut Bankir Indonesia, 1993.

\section{Peraturan Perundang-Undangan:}

Kitab Undang-Undang Hukum Perdata (KUHPerdata).

Kitab Undang-Undang Hukum Dagang (KUHD).

Undang-Undang Republik Indonesia Nomor 2 Tahun 1992 tentang Usaha Perasuransian.

Undang-Undang RI Nomor 10 Tahun 1998 tentang Perubahan atas Undang-Undang Nomor 7 Tahun 1992 tentang Perbankan.

Undang-Undang RI Nomor 8 Tahun 1999 tentang Perlindungan Konsumen.

Peraturan Pemerintah Republik Indonesia Nomor 1 Tahun 1971 tentang Penyertaan Modal Negara Republik Indonesia Untuk Pendirian Perusahaan Perseroan Dalam Bidang Perasuransian Kredit. 
Peraturan Bank Indonesia Nomor 7/2/PBI/2005 tentang Penilaian Kualitas Aktiva Bank Umum.

Surat Edaran Bank Indonesia Nomor 12/35/DPNP tahun 2010 tentang Penerapan Manajemen Risiko pada Bank yang Melakukan Aktivitas Kerjasama Pemasaran dengan Perusahaan Asuransi (Bancassurance).

Perjanjian Kredit Bank Pembangunan Daerah Sulawesi Tenggara Cabang Wakatobi Nomor: 227/KMG/135.006/04/12/Wci. 